\title{
Shewanella affinis sp. nov., isolated from marine invertebrates
}

\author{
Correspondence \\ Elena P. Ivanova \\ eivanova@swin.edu.au
}

\author{
Elena P. Ivanova, ${ }^{1,2}$ Olga I. Nedashkovskaya, ${ }^{2}$ Tomoo Sawabe, ${ }^{3}$ \\ Natalia V. Zhukova, ${ }^{4}$ Galina M. Frolova, ${ }^{2}$ Dan V. Nicolau, ${ }^{1}$ \\ Valery V. Mikhailov ${ }^{2}$ and John P. Bowman ${ }^{5}$ \\ ${ }^{1}$ Industrial Research Institute, Swinburne University of Technology, PO Box 218, Hawthorn,
Vic 3122, Australia \\ ${ }^{2}$ Pacific Institute of Bioorganic Chemistry of the Far-Eastern Branch of the Russian Academy \\ of Sciences, 690022 Vladivostok, Pr. 100 Let Vladivostoku 159, Russia \\ ${ }^{3}$ Laboratory of Microbiology, Graduate School of Fisheries Sciences, Faculty of Fisheries, \\ Hokkaido University, 3-1-1 Minato-cho, Hakodate 041-8611, Japan \\ ${ }^{4}$ Institute of Marine Biology of the Far-Eastern Branch of the Russian Academy of Sciences, \\ Palchevskogo Str. 17, 690041 Vladivostok, Russia \\ ${ }^{5}$ School of Agricultural Science, University of Tasmania, Private Bag 54, Hobart 7001, \\ Tasmania, Australia
}

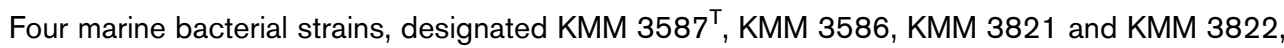
were isolated from the sipuncula Phascolosoma japonicum, a common inhabitant of Troitza Bay in the Gulf of Peter the Great (Sea of Japan region), and from an unidentified hydrocoral species collected in Makarov Bay (Iturup Islands), Kuril Islands, North-West Pacific Ocean. The strains were characterized to clarify their taxonomic position. 16S rRNA gene sequences of KMM $3587^{\top}$ and KMM 3586 indicated $99 \%$ similarity to Shewanella colwelliana. Despite such a high level of $16 \mathrm{~S}$ rRNA gene sequence similarity, DNA-DNA hybridization experiments demonstrated only $45-52 \%$ binding with DNA of S. colwelliana ATCC $39565^{\top}$. The DNA G +C contents of the novel strains were $45 \mathrm{~mol} \%$ and the shared level of DNA hybridization was conspecific (81-97\%), indicating that they represent a single genospecies. The novel strains were mesophilic (able to grow at $10-34{ }^{\circ} \mathrm{C}$ ), neutrophilic and haemolytic, and able to degrade gelatin, casein and Tween 20,40 and 80 , but not starch, agar, elastin, alginate or chitin. The major fatty acids were i13:0, i15:0, $16: 0,16: 1 \omega 7$ and $17: 1 \omega 8(68 \cdot 9 \%$ of total). The major isoprenoid quinones were Q7 (47-62\%) and Q8 (26-47\%). Eicosapentaenoic acid was produced in minor amounts. Based on these data, the strains are assigned to a novel species,

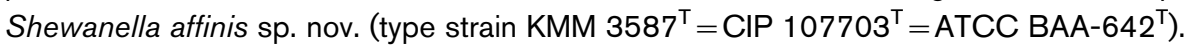

The genus Shewanella MacDonell and Colwell 1986 comprises an ubiquitous group of Gram-negative, aerobic and facultatively anaerobic $\gamma$-Proteobacteria (MacDonell \& Colwell, 1985; Gauthier et al., 1995; Venkateswaran et al., 1999; Garrity \& Holt, 2001; Satomi et al., 2003). This study involved the characterization of four Shewanella-like

Published online ahead of print on 19 December 2003 as DOI 10.1099/ijs.0.02992-0.

The GenBank/EMBL/DDBJ accession numbers for the 16S rRNA gene sequences of strains $\mathrm{KMM} 3587^{\top}$ and $\mathrm{KMM} 3586$ are AY351983 and AF500080, respectively.

Tables showing the cellular fatty acid composition and isoprenoid quinone composition of Shewanella affinis are available in IJSEM Online. bacteria that shared high levels of 16S rRNA gene sequence similarity (99\%) with Shewanella colwelliana (Ivanova et al., $2003 \mathrm{~b})$. One strain, KMM $3587^{\mathrm{T}}$, was isolated from the benthic marine 'peanut worm' (Phascolosoma japonicum; phylum Sipuncula), collected in 1997 from a depth of 3-5 m (salinity $32 \%$; temperature $18{ }^{\circ} \mathrm{C}$ ) at the Pacific Institute of Bio-organic Chemistry Marine Experimental Station, in Troitza Bay, Gulf of Peter the Great (Sea of Japan region). Three other strains (KMM 3586, KMM 3821 and KMM 3822) were isolated from an unidentified hydrocoral collected from Makarov Bay, Iturup Islands (Kuril Islands), North-West Pacific Ocean from a depth of $120 \mathrm{~m}$ (salinity $33 \%$; temperature $6{ }^{\circ} \mathrm{C}$ ). The procedures for invertebrate handling and strain isolation have been described elsewhere (Ivanova et al., 1996, 2003a, b). All 
strains were incubated on marine agar 2216 (Difco) or medium B, which contained: $0 \cdot 2 \%(\mathrm{w} / \mathrm{v})$ Bacto peptone (Difco); $0.2 \%(\mathrm{w} / \mathrm{v})$ casein hydrolysate (Merck); $0 \cdot 2 \%$ $(\mathrm{w} / \mathrm{v})$ Bacto yeast extract (Difco); $0.1 \%(\mathrm{w} / \mathrm{v})$ glucose; $0.02 \% \quad(\mathrm{w} / \mathrm{v}) \quad \mathrm{KH}_{2} \mathrm{PO}_{4} ; \quad 0.005 \% \quad(\mathrm{w} / \mathrm{v}) \quad \mathrm{MgSO}_{4} .7 \mathrm{H}_{2} \mathrm{O}$; $1.5 \%(\mathrm{w} / \mathrm{v})$ Bacto agar (Difco); $50 \%(\mathrm{v} / \mathrm{v})$ natural sea water; and $50 \%(\mathrm{v} / \mathrm{v})$ distilled water at $\mathrm{pH} 7 \cdot 8$. Agar plates were incubated aerobically at room temperature (about $22-25^{\circ} \mathrm{C}$ ) for $5-10$ days. The strains were stored at $-80{ }^{\circ} \mathrm{C}$ in marine broth 2216 (Difco) supplemented with $20 \%$ (v/v) glycerol.

Unless otherwise indicated, the phenotypic characteristics were studied using standard procedures (Baumann et al., 1972; Smibert \& Krieg, 1994) as described elsewhere (Ivanova et al., 1996, 1998, 2003a; Sawabe et al., 1998). The following physiological and biochemical properties were examined: oxidation/fermentation of glucose, denitrification, catalase and oxidase activities, gelatin liquefaction, arginine dihydrolase, lysine decarboxylase, ornithine decarboxylase, indole and $\mathrm{H}_{2} \mathrm{~S}$ production, and the ability to hydrolyse starch, alginate, chitin, elastin, Tween 20, 40 and 80 , and casein. The requirement for $\mathrm{Na}^{+}$ions was studied on a medium containing $(\mathrm{w} / \mathrm{v}): 0.25 \%$ yeast extract; $0.1 \%$ glucose; $0.02 \% \quad \mathrm{~K}_{2} \mathrm{HPO}_{4}$; and $0.005 \% \quad \mathrm{MgSO}_{4} .7 \mathrm{H}_{2} \mathrm{O}$ $(\mathrm{pH} 7 \cdot 8)$. Salt tolerance tests were performed on trypticase soy agar (TSA; Difco) with $\mathrm{NaCl}$ concentrations of $0 \cdot 6-20 \cdot 0 \%(\mathrm{w} / \mathrm{v})$. Dissimilatory iron reduction was tested on LM medium $[0.02 \%(\mathrm{w} / \mathrm{v})$ yeast extract, $0.01 \%(\mathrm{w} / \mathrm{v})$ peptone, $0.6 \%(\mathrm{w} / \mathrm{v}) \mathrm{NaCl}, 10 \mathrm{mM}$ sodium bicarbonate and $10 \mathrm{mM}$ HEPES] supplemented with carbon substrates as appropriate $(5 \mathrm{mM}$ lactate, $5 \mathrm{mM}$ succinate, $5 \mathrm{mM}$ glycerol, $1 \mathrm{mM}$ acetate), $50 \mathrm{mM}$ ferric citrate, $5 \mathrm{mM}$ sodium molybdate and the colour reagent ferrozine [3-(2-pyridyl)-5,6-bis(4-phenylsulfonic acid)-1,2,4 triazine, $\mathrm{pH} 7 \cdot 2]$ in distilled water. Plates were inoculated and incubated anaerobically at room temperature (for approx. 7 days) with positive and negative controls. Colonies displaying cleared zones were scored as positive for iron reduction. Haemolytic activity of the strains studied was detected on blood agar (40 g TSA in $50 \mathrm{ml}$ sheep blood and $950 \mathrm{ml}$ water). Haemolytic activity on mouse erythrocytes and cytotoxicity on Ehrlich cells were tested on butanol extracts of the strains as described earlier (Ivanova et al., 2001). Antimicrobial activity was assessed by the agar diffusion assay, based on the method described by Barry (1980). Cultures $(0 \cdot 1 \mathrm{ml})$ of indicator test strains were spread onto TSA plates in which circular wells $(10 \mathrm{~mm}$ diameter) had been cut. Samples $(0 \cdot 1 \mathrm{ml})$ of butanol extracts of the isolates were added to the wells and areas of inhibited bacterial growth were measured after incubation for $48 \mathrm{~h}$ at $28^{\circ} \mathrm{C}$. Zones of inhibited growth of the indicator strains surrounding the wells were observed. Mean diameters were measured and $10 \mathrm{~mm}$ was subtracted (representing the diameter of the well). Indicator test strains used were Staphylococcus aureus CIP 103594, Escherichia coli ATCC 15034, Proteus vulgaris IFO $3851^{\mathrm{T}}$, Enterococcus faecium CIP 104105, Bacillus subtilis ATCC
$6051^{\mathrm{T}}$ and the yeast Candida albicans KMM 455. Susceptibility to antibiotics was tested by the conventional diffusion plate technique using medium B agar and discs impregnated with the following antibiotics: kanamycin $(10 \mu \mathrm{g})$, ampicillin $(10 \mu \mathrm{g})$, benzylpenicillin $(10 \mu \mathrm{g})$, streptomycin $(10 \mu \mathrm{g})$, erythromycin $(15 \mu \mathrm{g})$, gentamicin $(10 \mu \mathrm{g})$, oxacillin $(20 \mu \mathrm{g})$, lincomycin $(15 \mu \mathrm{g})$, carbenicillin $(25 \mu \mathrm{g})$, vancomycin $(30 \mu \mathrm{g})$, tetracycline $(30 \mu \mathrm{g})$, oleandomycin $(15 \mu \mathrm{g})$ and $\mathrm{O} / 129(150 \mu \mathrm{g})$. Phenotypic analysis showed that all isolates were essentially identical to each other, exhibited haemolytic, but not cytotoxic or antimicrobial activities, and differed only in their ability to produce acid from arabinose and maltose and their susceptibility to some antibiotics: KMM $3587^{\mathrm{T}}$, KMM 3821 and KMM 3822 were susceptible to oleandomycin, whereas KMM 3586 was not; and KMM 3586 and KMM 3821 were also susceptible to carbenicillin, whereas the rest of the strains were not. The results of analysis of morphological and physiological properties are given in Table 1 and in the species description.

Table 1. Characteristics that differentiate Shewanella affinis from phylogenetically related species

Species: 1, Shewanella affinis; 2, Shewanella colwelliana; 3, Shewanella fidelis; 4, Shewanella pealeana; 5, Shewanella marinintestina; 6, Shewanella schlegeliana; 7, Shewanella sairae; 8, Shewanella gelidimarina; 9, Shewanella waksmanii; 10, Shewanella frigidimarina. All strains are Gram-negative, motile, rod-shaped organisms that are oxidase- and catalase-positive and can reduce nitrate to nitrite. V, Variable reaction depending on the strain; ND, data not available. Data from this study, Weiner et al. (1988), Bowman et al. (1997), Nogi et al. (1998), Venkateswaran et al. (1999), Skerratt et al. (2002), Satomi et al. (2003) and Ivanova et al. (2003a).

\begin{tabular}{|c|c|c|c|c|c|c|c|c|c|c|}
\hline Characteristic & 1 & 2 & 3 & 4 & 5 & 6 & 7 & 8 & 9 & 10 \\
\hline $\mathrm{G}+\mathrm{C}$ content $(\mathrm{mol} \%)$ & 45 & 46 & 45 & 45 & 43 & 45 & 43 & 48 & 43 & $40-43$ \\
\hline Pigments & - & - & - & - & - & - & - & - & + & - \\
\hline \multicolumn{11}{|l|}{ Growth at: } \\
\hline $4{ }^{\circ} \mathrm{C}$ & - & + & + & + & - & - & - & + & + & + \\
\hline $32^{\circ} \mathrm{C}$ & + & - & + & + & - & + & - & - & + & - \\
\hline $0 \% \mathrm{NaCl}$ & - & - & + & - & - & - & - & - & - & + \\
\hline $6 \% \mathrm{NaCl}$ & + & - & + & + & - & - & - & + & + & + \\
\hline Haemolysis & + & - & + & -1 & $\mathrm{ND}$ & ND & ND & - & + & ND \\
\hline \multicolumn{11}{|l|}{ Production of: } \\
\hline Lipase & + & + & $\mathrm{V}$ & + & + & - & + & + & + & + \\
\hline Amylase & - & + & - & - & - & - & - & - & - & - \\
\hline Gelatinase & + & + & + & - & + & + & + & + & + & + \\
\hline Chitinase & - & - & - & - & - & - & - & + & - & - \\
\hline \multicolumn{11}{|l|}{ Utilization of: } \\
\hline D-Galactose & - & - & - & + & - & - & - & - & - & + \\
\hline DL-Lactate & - & - & - & + & - & - & - & + & - & + \\
\hline Succinate & - & - & - & + & - & - & - & - & - & - \\
\hline Citrate & - & - & - & + & - & - & - & - & - & - \\
\hline
\end{tabular}


Analysis of fatty acid methyl esters was performed by GLC as described previously by Svetashev et al. (1995). Isoprenoid quinones were extracted from lyophilized cells and analysed as described by Moule \& Wilkinson (1987) and elsewhere (Ivanova et al., 2003b). The cellular fatty acid profile was typical for Shewanella and included saturated, monoenoic, monounsaturated, straight-chain and iso-branched components, namely $(\% \pm S D)$ i i $13: 0 \quad(6 \cdot 7 \pm 3 \cdot 4)$; i15:0 $(20 \cdot 1 \pm 10 \cdot 0) ; 15: 0(6 \cdot 8 \pm 1 \cdot 6) ; 16: 0(6 \cdot 9 \pm 4 \cdot 3) ; 16: 1 \omega 7$ $(21 \cdot 5 \pm 5 \cdot 6)$; and $17: 1 \omega 8(14 \cdot 1 \pm 4 \cdot 6)$ (see supplementary material in IJSEM Online). The strains produced up to $2 \cdot 1 \%$ of their total fatty acids as $20: 5 \omega 3$ (eicosapentaenoic fatty acid) when grown at $28^{\circ} \mathrm{C}$.

The almost-complete 16S rRNA gene sequences for KMM $3587^{\mathrm{T}}$ and KMM 3586 were amplified and sequenced as described elsewhere (Ivanova et al., 2001, 2003a, b) and compared to the GenBank nucleotide database using online BLAST searches. 16S rRNA gene sequences of Shewanella species (if available) were aligned and analysed in the program BIOEDIT using PHYLIP version 3.57c (Felsenstein, 1993). DNADIST was used to determine sequence similarities using the maximum-likelihood algorithm option. Phylogenetic trees were constructed with the neighbourjoining method using the program NEIGHBOR. The outgroup on the Shewanella trees was Psychromonas antarctica DSM $10704^{\mathrm{T}}$ (GenBank accession no. Y14697). According to phylogenetic analysis, strains KMM $3587^{\mathrm{T}}$ and KMM 3586 formed a cluster with $S$. colwelliana ATCC 33888 and shared high (99\%) 16S rRNA gene sequence similarity (Fig. 1).

DNA was extracted from cells grown overnight on medium B following the method of Marmur (1961). DNA-DNA hybridization was performed spectrophotometrically and initial renaturation rates were recorded as described elsewhere (Marmur \& Doty, 1962; De Ley et al., 1970; Bowman et al., 1998). The $\mathrm{G}+\mathrm{C}$ content of the DNA ranged from $45 \cdot 2 \pm 0 \cdot 5$ to $45 \cdot 4 \pm 0 \cdot 3 \mathrm{~mol} \%$. DNA-DNA hybridization data revealed high intraspecies levels of DNA relatedness among the four strains (81-97\%). S. colwelliana ATCC $39565^{\mathrm{T}}$ was obtained from the American Type Culture Collection. DNA hybridization analysis indicated that hybridization between DNA of $S$. colwelliana ATCC $39565^{\mathrm{T}}$ and the novel isolates was $45-52 \%$. This clearly indicates that the strains investigated in this study belong to the same genospecies, but are separate (Wayne et al., 1987; Stackebrandt \& Goebel, 1994) from S. colwelliana, which is also derived from an invertebrate, the eastern oyster (Crassostrea virginica) (Coyne et al., 1989). Thus, levels of genetic relatedness according to DNA-DNA hybridization experiments were less than $70 \%$, which leads to the conclusion that the isolates represent a novel and distinct species. Strains of the novel species can be phenotypically, chemotaxonomically and genetically distinguished from other species, in particular from $S$. colwelliana, by a combination of phenotypic traits listed in Table 1, including

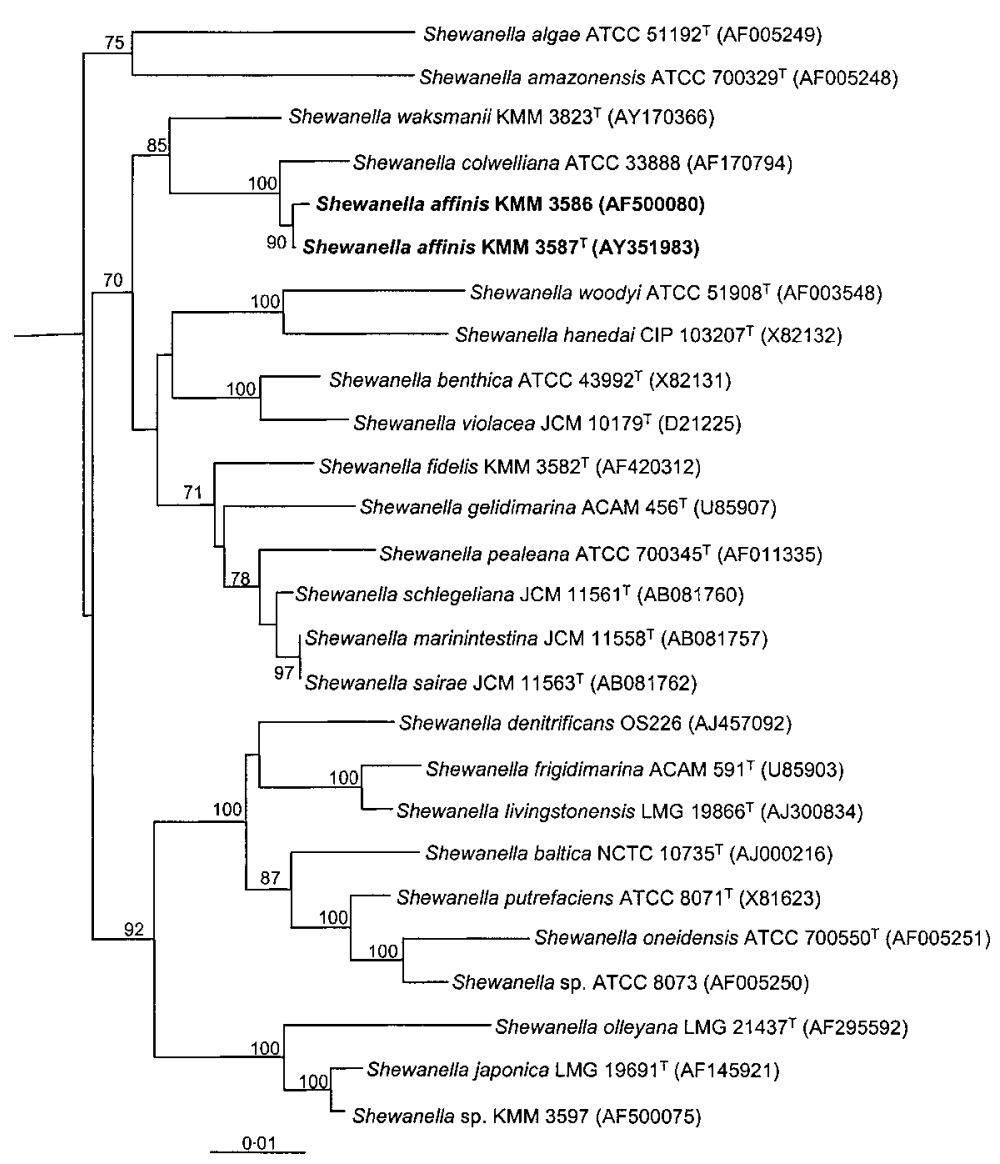

Fig. 1. Phylogenetic position of Shewanella affinis according to $16 \mathrm{~S}$ rRNA gene sequence analysis. The tree was generated from maximum-likelihood distances clustered by the neighbour-joining method. Bootstrap values, expressed as a percentage of 1000 replications, are given at branching points. 
pigmentation, different growth temperatures, tolerance to $6 \% \mathrm{NaCl}$, haemolytic ability, lack of amylase activity, different Biolog substrate utilization pattern and cellular fatty acid profile.

\section{Description of Shewanella affinis sp. nov.}

Shewanella affinis (af.fi'nis. L. fem. adj. affinis adjoining, a novel bacterium that has joined the genus Shewanella).

Cells are rod-shaped, $1 \cdot 0-2 \cdot 0 \times 0 \cdot 6-0 \cdot 8 \mu \mathrm{m}$ and polarly flagellated, although some strains are non-flagellated. Gram-negative, facultatively anaerobic heterotroph. Anaerobic growth occurs by fermentation of D-glucose by anaerobic respiration of nitrate. No endospores are formed. Colonies on marine agar 2216 are circular, smooth, convex with an entire edge and slightly pinkish. Organic growth factors are not required. Has an absolute requirement for $\mathrm{Na}^{+}$ions and grows in $0 \cdot 5-6.0 \% \mathrm{NaCl}$; some strains (KMM 3821 and KMM 3822) grow in $8 \% \mathrm{NaCl}$. Temperature of growth is $10-34^{\circ} \mathrm{C}$; optimum growth occurs at $20-25^{\circ} \mathrm{C}$ and no growth is detected at $37^{\circ} \mathrm{C}$. Oxidaseand catalase-positive. Reduces nitrate to nitrite. Arginine dihydrolase and lysine decarboxylase are not detected. Haemolytic. Has esterase (Tween 20, 40, 80) and proteinase (caseinase, gelatinase) activities, whereas amylase, alginase, elastinase, agarase and chitinase activities are not found. $\mathrm{H}_{2} \mathrm{~S}$ is formed from thiosulfate anaerobically. Indole is not formed from L-tryptophan. Voges-Proskauer test is negative. D-Glucose is utilized as sole source of carbon. Susceptible to gentamicin; some strains susceptible to oleandomycin, kanamycin and streptomycin (see text). Utilizes limited range of carbon sources according to Biolog: DL-lactic acid and L-asparagine. Weakly utilizes methyl $\beta$-D-glucoside, D-psicose, D-raffinose, sucrose, turanose, succinic acid monomethyl ester, acetic acid, cis-aconitic acid, L-ornithine, L-serine, 2-aminoethanol, 2,3-butanediol, DL- $\alpha$-glycerol phosphate and D-glucose 6-phosphate. The major cellular fatty acids are i13:0,

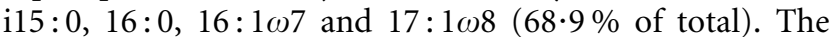
major isoprenoid quinones are Q7 (47-62\%) and Q8 $(26-47 \%)$. Eicosapentaenoic fatty acid $(20: 5 \omega 3)$ is produced in minor amounts. Isolated from benthic marine worms of the species Phascolosoma japonicum collected in Troitza Bay, Gulf of Peter the Great (Sea of Japan region) and from a hydrocoral species collected in the Kuril Islands (Makarov Bay, Iturup Islands) North-West Pacific Ocean. DNA G + C content is $45 \cdot 2 \pm 0 \cdot 5$ to $45 \cdot 4 \pm 0 \cdot 3 \mathrm{~mol} \%$.

Type strain is $\mathrm{KMM} 3587^{\mathrm{T}}\left(=\mathrm{CIP} 107703^{\mathrm{T}}=\mathrm{ATCC}\right.$ BAA- $\left.642^{\mathrm{T}}\right)$.

\section{Acknowledgements}

This study was partially supported by funds from the Russian Foundation for Basic Research (RFBR) 02-04-49517, grant 03-19 from the Ministry for Industry, Science and Technology of Russian Federation and grant 03-1-0-05-005 from the Far-Eastern Branch of the Russian Academy of Sciences.

\section{References}

Barry, A. I. (1980). Procedures and theoretical considerations for testing antimicrobial agents in agar media. In Antibiotics in Laboratory Medicine, pp. 10-16. Edited by V. Logan. Baltimore, MD: Williams \& Wilkins.

Baumann, L., Baumann, P., Mandel, M. \& Allen, R. D. (1972). Taxonomy of aerobic marine eubacteria. J Bacteriol 110, 402-429.

Bowman, J. P., McCammon, S. A., Nichols, D. S., Skerratt, J. H., Rea, S. M., Nichols, P. D. \& McMeekin, T. A. (1997). Shewanella gelidimarina sp. nov. and Shewanella frigidimarina sp. nov., novel Antarctic species with the ability to produce eicosapentaenoic acid $(20: 5 \omega 3)$ and grow anaerobically by dissimilatory Fe(III) reduction. Int J Syst Bacteriol 47, 1040-1047.

Bowman, J. P., McCammon, S. A., Brown, J. L. \& McMeekin, T. A. (1998). Glaciecola punicea gen. nov., sp. nov. and Glaciecola pallidula gen. nov., sp. nov.: psychrophilic bacteria from Antarctic sea-ice habitats. Int J Syst Bacteriol 48, 1213-1222.

Coyne, V. E., Pillidge, C. J., Sledjeski, D. D., Hori, H., Ortiz-Conde, B. A., Muir, D. G., Weiner, R. M. \& Colwell, R. R. (1989). Reclassification of Alteromonas colwelliana to the genus Shewanella by DNA-DNA hybridisation, serology and 5S ribosomal RNA sequence data. Syst Appl Microbiol 12, 275-279.

De Ley, J., Cattoir, H. \& Reynaerts, A. (1970). The quantitative measurement of DNA hybridization from renaturation rates. Eur J Biochem 12, 143-153.

Felsenstein, J. (1993). PHYLIP (phylogeny inference package), version 3.5c. Department of Genetics, University of Washington, Seattle, USA.

Garrity, G. M. \& Holt, J. G. (2001). The road map to the Manual. In Bergey's Manual of Systematic Bacteriology, 2nd edn, vol. 1, p. 119-166. Edited by D. R. Boone \& R. W. Castenholz. New York: Springer.

Gauthier, G., Gauthier, M. \& Christen, R. (1995). Phylogenetic analysis of the genera Alteromonas, Shewanella, and Moritella using genes coding for small-subunit rRNA sequences and division of the genus Alteromonas into two genera, Alteromonas (emended) and Pseudoalteromonas gen. nov., and proposal of twelve new species combinations. Int J Syst Bacteriol 45, 755-761.

Ivanova, E. P., Kiprianova, E. A., Mikhailov, V. V., Levanova, G. F., Garagulya, A. D., Gorshkova, N. M., Yumoto, N. \& Yoshikawa, S. (1996). Characterization and identification of marine Alteromonas nigrifaciens strains and emendation of the description. Int J Syst Bacteriol 46, 223-228.

Ivanova, E. P., Kiprianova, E. A., Mikhailov, V. V. \& 8 other authors (1998). Phenotypic diversity of Pseudoalteromonas citrea from different marine habitats and emendation of the description. Int J Syst Bacteriol 48, 247-256.

Ivanova, E. P., Sawabe, T., Gorshkova, N. M., Svetashev, V. I., Mikhailov, V. V., Nicolau, D. V. \& Christen, R. (2001). Shewanella japonica sp. nov. Int J Syst Evol Microbiol 51, 1027-1033.

Ivanova, E. P., Nedashkovskaya, O. I., Zhukova, N. V., Nicolau, D. V., Christen, R. \& Mikhailov, V. V. (2003a). Shewanella waksmanii sp. nov., isolated from a sipuncula (Phascolosoma japonicum). Int J Syst Evol Microbiol 53, 1471-1477.

Ivanova, E. P., Sawabe, T., Zhukova, N. V. \& 8 other authors (2003b). Occurrence and diversity of mesophilic Shewanella strains isolated from the North-West Pacific Ocean. Syst Appl Microbiol 26, 293-301.

MacDonell, M. T. \& Colwell, R. R. (1985). Phylogeny of the Vibrionaceae, and recommendation for two new genera, Listonella and Shewanella. Syst Appl Microbiol 6, 171-182. 
Marmur, J. (1961). A procedure for the isolation of deoxyribonucleic acid from microorganisms. J Mol Biol 3, 208-218.

Marmur, J. \& Doty, P. (1962). Determination of the base composition of deoxyribonucleic acid from its thermal denaturation temperature. J Mol Biol 4, 109-118.

Moule, A. L. \& Wilkinson, S. G. (1987). Polar lipids, fatty acids and isoprenoid quinones of Alteromonas putrefaciens (Shewanella putrefaciens). Syst Appl Microbiol 9, 192-198.

Nogi, Y., Kato, C. \& Horikoshi, K. (1998). Taxonomic studies of deep-sea barophilic Shewanella strains and description of Shewanella violacea sp. nov. Arch Microbiol 170, 331-338.

Satomi, M., Oikawa, H. \& Yano, Y. (2003). Shewanella marinintestina sp. nov., Shewanella schlegeliana sp. nov. and Shewanella sairae sp. nov., novel eicosapentaenoic-acid-producing marine bacteria isolated from sea-animal intestines. Int J Syst Evol Microbiol 53, 491-499.

Sawabe, T., Makino, H., Tatsumi, M., Nakano, K., Tajima, K., Iqbal, M. M., Yumoto, I., Ezura, Y. \& Christen, R. (1998). Pseudoalteromonas bacteriolytica sp. nov., a marine bacterium that is the causative agent of red spot disease of Laminaria japonica. Int J Syst Bacteriol 48, 769-774.

Skerratt, J. H., Bowman, J. P. \& Nichols, P. D. (2002). Shewanella olleyana sp. nov., a marine species isolated from a temperate estuary which produces high levels of polyunsaturated fatty acids. Int J Syst Evol Microbiol 52, 2101-2106.

Smibert, R. M. \& Krieg, N. R. (1994). Phenotypic characterization. In Methods for General and Molecular Bacteriology, pp. 607-654. Edited by P. Gerhardt, R. G. E. Murray, W. A. Wood \& N. R. Krieg. Washington, DC: American Society for Microbiology.

Stackebrandt, E. \& Goebel, B. M. (1994). Taxonomic note: a place for DNA-DNA reassociation and 16S rRNA sequence analysis in the present species definition in bacteriology. Int J Syst Bacteriol 44, 846-849.

Svetashev, V. I., Vysotskii, M. V., Ivanova, E. P. \& Mikhailov, V. V. (1995). Cellular fatty acid of Alteromonas species. Syst Appl Microbiol 18, 37-43.

Venkateswaran, K., Moser, D. P., Dollhopf, M. E. \& 10 other authors (1999). Polyphasic taxonomy of the genus Shewanella and description of Shewanella oneidensis sp. nov. Int J Syst Bacteriol 49, 705-724.

Wayne, L. G., Brenner, D. J., Colwell, R. R. \& 9 other authors (1987). International Committee on Systematic Bacteriology. Report of the ad hoc committee on reconciliation of approaches to bacterial systematics. Int J Syst Bacteriol 37, 463-464.

Weiner, R. M., Coyne, V. E., Brayton, P., West, P. \& Raiken, S. F. (1988). Alteromonas colwelliana sp. nov., an isolate from oyster habitats. Int J Syst Bacteriol 38, 240-244. 